\title{
Identification of Protein Receptors for Coronaviruses by Mass Spectrometry
}

\author{
V. Stalin Raj, Mart M. Lamers, Saskia L. Smits, Jeroen A.A. Demmers, \\ Huihui Mou, Berend-Jan Bosch, and Bart L. Haagmans
}

\begin{abstract}
As obligate intracellular parasites, viruses need to cross the plasma membrane and deliver their genome inside the cell. This step is initiated by the recognition of receptors present on the host cell surface. Receptors can be major determinants of tropism, host range, and pathogenesis. Identifying virus receptors can give clues to these aspects and can lead to the design of intervention strategies. Interfering with receptor recognition is an attractive antiviral therapy, since it occurs before the viral genome has reached the relative safe haven within the cell. This chapter describes the use of an immunoprecipitation approach with Fc-tagged viral spike proteins followed by mass spectrometry to identify and characterize the receptor for the Middle East respiratory syndrome coronavirus. This technique can be adapted to identify other viral receptors.
\end{abstract}

Key words Receptor, DPP4, Middle East respiratory syndrome coronavirus, Mass spectrometry, Immunoprecipitation

\section{Introduction}

The first step of the infection cycle of a virus is characterized by the interaction between the viral particle and the cell surface receptor. This interaction is followed by a series of events that lead to the delivery of the viral genome inside the cytoplasm. Viruses can use diverse types of molecules to bind and enter cells. The presence of a receptor is the principal determinant of cell, tissue and organ tropism, host range, and virulence. Therefore, identifying a receptor can give clues on pathogenesis, mode of transmission, zoonotic transmission potential and can lead to the design of targeted intervention strategies. 
For the last three decades the identification of virus receptors has been a major goal in virology. A group of viruses of which many receptors are known are coronaviruses (CoVs). Coronaviruses infect a wide range of avian and mammalian hosts and they are known for their ability to cross the species barrier [1]. This is exemplified by the 2003 severe acute respiratory syndrome (SARS) pandemic that was caused by the SARS-CoV [2]. In 2012, a novel zoonotic $\mathrm{CoV}$ was identified from a patient from Saudi Arabia that presented with a severe pneumonia [3]. This virus belongs to the same genus as SARS-CoV and was named Middle East respiratory syndrome coronavirus (MERS-CoV).

For CoVs, the viral Spike (S) protein primarily determines host and cell tropism. It is a type I membrane glycoprotein that is assembled in trimers in the viral envelope. The $S$ protein can be functionally divided into two distinct subunits, S1 and S2. The S1 subunit binds to a cell surface receptor, whereas S2 facilitates fusion with cellular membranes.

Although virus receptors can be identified using several methods [4-8], we identified the MERS-CoV receptor using Fc-tagged S1 proteins in an immunoprecipitation assay followed by mass spectrometry [9]. This assay is basically similar to the method described by $\mathrm{Li}$ et al., for the identification of the SARS-CoV receptor [10]. In this assay, the SI subunit of MERS-CoV is ligated into a fusion vector to generate an Sl-Fc fusion protein, for expression in HEK-293T cells and purification using protein A-sepharose beads. Incubation of the SI-Fc proteins with whole cell lysate of virus-susceptible cells allows the precipitation of the virus receptor with the tagged S1. This complex can then be pulled down from the lysate using protein A-sepharose beads. Subsequently, mass spectrometry is employed to identify candidate protein receptors (Fig. 1). These candidates must be evaluated functionally, which is done using flow-cytometric binding assays, infection blocking experiments using antibodies against the candidate receptor, and finally by attempting to infect non-susceptible cells that have been transfected with the candidate receptor. This method has been successfully employed for the rapid identification of the SARS-CoV and MERS-CoV receptor $[9,10]$ and is suitable for identification of protein receptors with reasonable affinity. Glycan receptors cannot be identified using the described method; treatment of susceptible cells with glycosidases prior to infection can give an insight into the type of viral receptor. Success of the protein receptor pulldown using the SI-Fc as bait depends on the affinity of S1-receptor interaction. A FACS-based SI-Fc cell-binding assay provides good insight in the strength of this interaction. The FACS-based S1-Fc assay is also instrumental to identify cell lines with high levels of receptor expression that can be used as a source for receptor affinity-isolation. Alternatively, in the absence of a suitable cell line, homogenates of tissue targeted by the virus can also be used for immunoprecipitation of the receptor. 

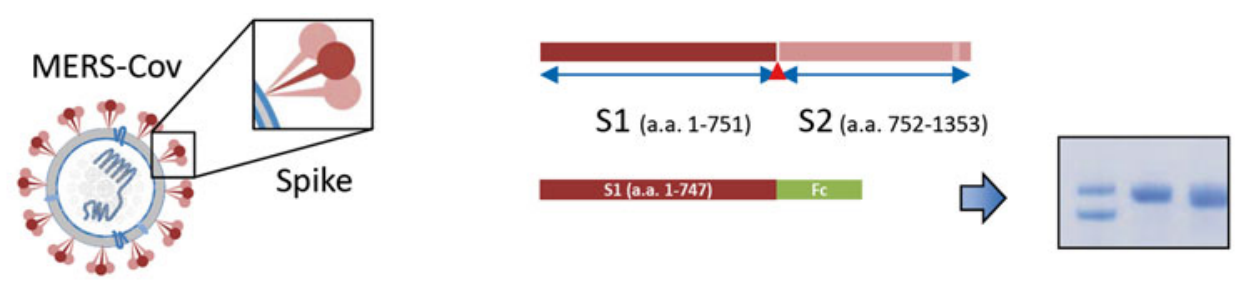

DPP4 peptides

MKTAWKVLLG LLGAAALVTI ITVPVVLLNK

GTDDATADSR KTYTLTDYLK NTYRLKLYSL

RWISDHEYLY KQENNILVFN AEYGNSSVFI

ENSTFDEFGH SINDYSISPD GQFILLEYNY

VKQWRHSYTA SYDIYDINKR QLITEERIPN
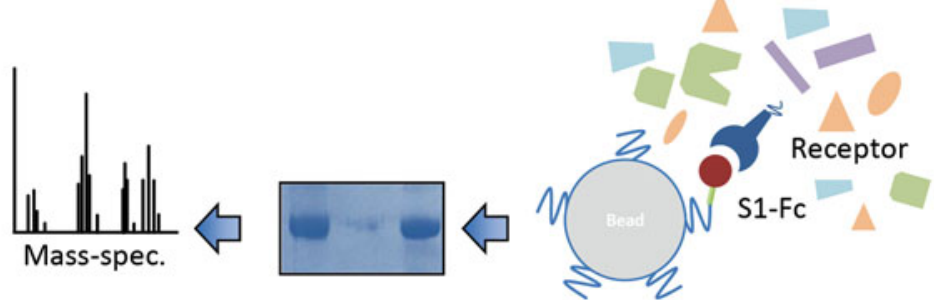

NTQWVTWSPV GHKLAYVWNN DIYVKIEPNL

Fig. 1 Schematic drawing of the identification of the MERS-CoV receptor. The S1 subunit of the MERS-CoV S protein is expressed as an IgG Fc-tagged protein in HEK-293T cells and purified using protein A-sepharose beads. Incubating the S1-Fc protein with whole cell lysate of susceptible cells allows the precipitation of the virus protein receptor with the tagged $\mathrm{S} 1$. This complex can be pulled down from the lysate using protein A-sepharose beads. Subsequently, mass spectrometry is employed to identify candidate receptors

\section{Materials}

\subsection{RNA Isolation, cDNA Synthesis, PCR, and Cloning}

1. The virus used in this protocol is used as an example. A stock of MERS-CoV-EMC isolate was prepared at $10^{7} \mathrm{TCID}_{50} / \mathrm{ml}$ and stored at $-70^{\circ} \mathrm{C}$.

2. RNA isolation: viral RNA isolation kit or tissue RNA isolation kit (Qiagen) or equivalent.

3. Reverse transcriptase, e.g., SuperScript II or equivalent.

4. $100 \mathrm{mM}$ dithiothreitol (DTT).

5. RNase inhibitor.

6. $10 \mathrm{mM}$ random primers.

7. Pfu Ultra II Fusion HS DNA polymerase or equivalent.

8. $10 \mathrm{mM}$ dNTPs.

9. $10 \mathrm{mM}$ gene specific forward primer, e.g., MERS-CoV S1 forward primer cgaattcaccATGATACACTCAGTGTTTCTAC: the nucleotides in upper case represent MERS-CoV and those in lower case a suitable restriction endonuclease site for cloning purposes; the example here contains an EcoRI site.

10. $10 \mathrm{mM}$ gene specific reverse primer, e.g., MERS-CoV S1 reverse primer cggatccGGTGTGAGAGTACTAGGTGTC: 


\subsection{Expression of S1-Fc Fusion Proteins}

the nucleotides in upper case represent MERS-CoV and those in lower case a suitable restriction endonuclease site for cloning purposes; the example here contains a BamHI site.

11. PCR cleanup kit.

12. DNA gel extraction kit.

13. Competent E. coli, e.g., Topl0 competent cells.

14. Cloning vectors: pCAGGS (Addgene), pFUSE-hIgG1-Fc2 (InvivoGen), and pCDNA3.1(+) (Life Technologies) or similar.

15. Restriction enzymes, e.g., EcoRI and BamHI.

16. SOC medium: $2 \% \mathrm{w} / \mathrm{v}$ tryptone, $0.5 \% \mathrm{w} / \mathrm{v}$ yeast extract, $10 \mathrm{mM} \mathrm{NaCl}, 2.5 \mathrm{mM} \mathrm{KCl}, 10 \mathrm{mM} \mathrm{MgSO} 4,20 \mathrm{mM}$ glucose. Adjust to $\mathrm{pH} 7.5$ using $\mathrm{NaOH}$.

17. T4 DNA Ligase.

18. Maxi prep DNA kit (Qiagen) or equivalent.

19. LB medium: $1 \% \mathrm{w} / \mathrm{v}$ tryptone, $0.5 \% \mathrm{w} / \mathrm{v}$ yeast extract, $1 \% \mathrm{w} / \mathrm{v} \mathrm{NaCl}$. Adjust $\mathrm{pH}$ to 7.0 with $5 \mathrm{~N} \mathrm{NaOH}$. Sterilize by autoclaving.

20. LB Amp medium: LB medium, $100 \mu \mathrm{g} / \mathrm{ml}$ ampicillin added after sterilization. Store at $4{ }^{\circ} \mathrm{C}$.

21. LB Amp plates: LB medium, $1.5 \%$ agar added prior to sterilization. Sterilize by autoclaving and allow to cool to $45^{\circ} \mathrm{C}$. Add ampicillin to a final concentration of $100 \mu \mathrm{g} / \mathrm{ml}$. Dispense into $90 \mathrm{~mm}$ petri dishes and store at $4{ }^{\circ} \mathrm{C}$.

1. HEK-293T cells. HEK-293T growth medium: DMEM, $10 \%$ fetal calf serum (FCS), $100 \mathrm{U} / \mathrm{ml}$ penicillin, $100 \mathrm{mg} / \mathrm{ml}$ streptomycin, $2 \mathrm{mM}$ glutamine, 1 \% nonessential amino acids, and $1 \mathrm{mM}$ sodium pyruvate.

2. T175 cell culture flasks.

3. 293T cell expression medium (as described in ref. 11) 293SF II medium (life Technologies), I \% GlutaMAX, $0.3 \%$ primatone, $0.2 \%$ glucose, $0.37 \% \mathrm{NaHCO}_{3}$ and $1.5 \%$ DMSO.

4. Serum-free DMEM.

$5.1 \mathrm{mg} / \mathrm{ml}$ Polyethylenimine (PEI) stock solution: Add $50 \mathrm{mg}$ PEI to $50 \mathrm{ml}$ of endotoxin-free $\mathrm{dH}_{2} \mathrm{O}$, place in a $75^{\circ} \mathrm{C}$ water bath and vortex every 10 min until completely dissolved, cool to room temperature, neutralize to $\mathrm{pH} 7.0$, filter-sterilize using a $0.22 \mu \mathrm{m}$ filter, aliquot and store at $-20^{\circ} \mathrm{C}$.

6. Protein-A sepharose CL-4B (GE Healthcare) or equivalent.

7. 1 M Tris- $\mathrm{HCl} \mathrm{pH} 8.0$.

8. Protein elution buffer: $0.5 \mathrm{M}$ acetic acid $\mathrm{pH} 3$. Add $29 \mathrm{ml}$ of acetic acid to a beaker, make up to $1 \mathrm{l}$ by adding $971 \mathrm{ml} \mathrm{dH}_{2} \mathrm{O}$, adjust to $\mathrm{pH} 3$ using $\mathrm{NaOH}$.

9. $3 \mathrm{M}$ Tris- $\mathrm{HCl} \mathrm{pH} 8.8$. 


\subsection{Immunopreci- pitaion}

\subsection{Mass Spectrometry}

1. Huh-7 cells

2. Huh-7 growth medium: RPMIl640, $10 \%$ FCS, $100 \mathrm{U} / \mathrm{ml}$ penicillin, and $100 \mathrm{mg} / \mathrm{ml}$ streptomycin.

3. $100 \mathrm{~mm}$ cell culture dishes.

4. Phosphate-buffered saline (PBS).

5. Protein-A sepharose CL-4B (GE Health care) or equivalent.

6. Protein elution buffer: $0.5 \mathrm{M}$ acetic acid $\mathrm{pH} 3$ as in Subheading 2.2.

7. Lysis buffer: $3.3 \mathrm{mg} / \mathrm{ml} \quad n$-decyl- $\beta$-D-maltopyranoside (DDM), protease inhibitor cocktail complete Mini (Roche).

8. Rubber policemen or plastic cell scrapers.

1. Tris-Glycine SDS sample buffer $2 \times: 1.25 \mathrm{ml} \mathrm{l} \mathrm{M} \mathrm{Tris-HCl}$ $(\mathrm{pH} 6.8), 4 \mathrm{ml} 10 \%(\mathrm{w} / \mathrm{v})$ SDS, $2 \mathrm{ml}$ glycerol, $1 \mathrm{ml} 0.1 \%$ (w/v) bromophenol Blue, $1 \mathrm{ml} 2 \mathrm{M}$ DTT, make up to $10 \mathrm{ml}$ with distilled water and store at room temperature.

2. $10 \%$ pre-cast Tris-Glycine SDS-PAGE gels (Bio-Rad) or equivalent.

3. Tris-Glycine SDS Running buffer: $250 \mathrm{mM}$ Tris base, $1,920 \mathrm{mM}$ glycine, $1.0 \%$ SDS, $\mathrm{pH} 8.3$.

4. Absolute methanol.

5. Coomassie blue staining solution: $100 \mathrm{mg}$ of Coomassie brilliant Blue R250, $10 \mathrm{ml}$ acetic acid, $50 \mathrm{ml}$ methanol, $40 \mathrm{ml}$ $\mathrm{dH}_{2} \mathrm{O}$.

6. Destaining solution: $10 \mathrm{ml}$ acetic acid, $50 \mathrm{ml}$ methanol, and $40 \mathrm{ml} \mathrm{dH}{ }_{2} \mathrm{O}$.

7. $100 \mathrm{mM}$ ammonium bicarbonate $\left(\mathrm{NH}_{4} \mathrm{HCO}_{3}\right)$.

8. Acetonitrile.

9. $50 \mathrm{mM} \mathrm{NH}_{4} \mathrm{HCO}_{3}$.

10. $20 \mathrm{mM}$ dithiothreitol (DTT).

11. $200 \mathrm{mM}$ Tris(carboxyethyl)phosphine (TCEP).

12. $55 \mathrm{mM}$ iodoacetamide (IAA).

13. Trypsin, mass spectrometry grade.

14. Trypsin stock solution: dissolve $100 \mu \mathrm{g}$ of trypsin in $1 \mathrm{ml}$ of $1 \mathrm{mM} \mathrm{HCl}$, aliquot into $10 \mu \mathrm{l} \mathrm{samples,} \mathrm{store} \mathrm{at}-80^{\circ} \mathrm{C}$.

15. $0.5 \%$ formic acid in $30 \%$ acetonitrile.

16. Razor blade and tweezers.

17. Filter paper.

18. Mickle gel slicer (Brinkman) or equivalent.

19. Ultrasonic water bath.

20. SpeedVac. 
21. EASY-nLC coupled to a Q Exactive mass spectrometer (both Thermo Scientific).

22. ReproSil C18 reversed-phase column (Dr. Maisch GmbH).

2.5 Validation

of Receptor Identification
1. Cos-7 cells.

2. Cos-7 cell growth medium: DMEM, $10 \%$ FCS, $100 \mathrm{U} / \mathrm{ml}$ penicillin, and $100 \mathrm{mg} / \mathrm{ml}$ streptomycin.

3. Trypsin-EDTA: $0.25 \% \mathrm{w} / \mathrm{v}$ trypsin, $0.02 \% \mathrm{w} / \mathrm{v}$ EDTA in PBS.

4. Hemocytometer or cell counting chamber.

5. Anti-DPP4 or antibody against other protein of interest.

6. Flow cytometer.

7. $4 \%$ formaldehyde.

8. $10 \%$ normal goat serum or serum corresponding species from which secondary antibody is raised.

9. Anti-SARS nsp4 or antibody against other viral protein.

10. Goat anti-rabbit FITC or other suitable secondary antibody.

11. Fluorescence microscope.

\section{Methods}

\subsection{RNA Isolation}

The virus used in this method, MERS-CoV EMC, was described previously [12] and is used as an example.

1. Isolate viral RNA from $140 \mu \mathrm{l}$ of virus stock at $10^{7} \mathrm{TCID}_{50} /$ $\mathrm{ml}$ using the viral RNA isolation kit, following manufacturer's instructions. The tissue RNA isolation kit was used to isolate RNA from $2 \times 10^{7}$ Huh-7 cells, following manufacturer's instructions ( see Note $\mathbf{1}$ ).

\section{2 cDNA Synthesis}

To convert RNA into cDNA we use SuperScript II reverse transcriptase but other reverse transcriptase enzymes can also be used.

1. For a $20 \mu \mathrm{l}$ reaction mix, $10 \mu \mathrm{l}$ RA, $1 \mu \mathrm{l} 10 \mathrm{mM}$ dNTPs, $1 \mu \mathrm{l}$

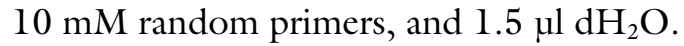

2. Incubate at $65{ }^{\circ} \mathrm{C}$ for $10 \mathrm{~min}$ and then at $4{ }^{\circ} \mathrm{C}$ for $2 \mathrm{~min}$ (see Note 2).

3. Place on ice.

4. Make reverse transcriptase (RT) mix (for a $20 \mu l$ total reaction volume) as follows: $4 \mu \mathrm{l} 5 \times$ SuperScript II reaction buffer, $1 \mu \mathrm{l}$ $100 \mathrm{mM}$ DTT, $0.5 \mu \mathrm{l}$ RNase inhibitor $(20 \mathrm{U} / \mu \mathrm{l}), 1 \mu \mathrm{l} 10 \mathrm{mM}$ random primers (Promega), and $1 \mu$ l SuperScript II reverse transcriptase $(200 \mathrm{U} / \mu \mathrm{l})$.

5. Add $6.5 \mu \mathrm{l}$ of RT mix and incubate as follows: $25^{\circ} \mathrm{C}$ for $5 \mathrm{~min}$, $50{ }^{\circ} \mathrm{C}$ for $45 \mathrm{~min}, 70{ }^{\circ} \mathrm{C}$ for $20 \mathrm{~min}$.

6. Store at $4{ }^{\circ} \mathrm{C}$. 


\subsection{PCR \\ Amplification \\ of the S1 Region}

\subsection{Cloning and Expression of the S1-Fc Fusion Protein}

We strongly recommend the use of Pfu Ultra II Fusion HS DNA polymerase, although other enzymes may be used. The PCR instructions in this protocol are optimized for the use of this polymerase.

1. Prepare the PCR mix (48 $\mu$ l reaction volume) as follows: $5.0 \mu \mathrm{l} \mathrm{10 \times} \mathrm{Pfu} \mathrm{Ultra} \mathrm{II} \mathrm{Fusion} \mathrm{HS} \mathrm{DNA} \mathrm{polymerase} \mathrm{buffer,}$ $2.5 \mu l 10 \mathrm{mM}$ dNTPs, $1.5 \mu l 10 \mathrm{mM}$ gene specific forward primer, $1.5 \mu l 10 \mathrm{mM}$ gene specific reverse primer, $1.0 \mu \mathrm{Pfu}$

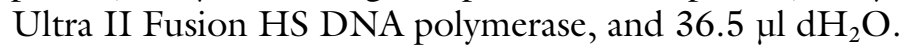

2. Add $2.0 \mu \mathrm{l}$ of the cDNA reaction mix from Subheading 3.2, step 6 to the $48 \mu \mathrm{l}$ PCR mix and mix by pipetting the solution up and down several times.

3. Incubate the PCR cDNA mix as follows: $94^{\circ} \mathrm{C}$ for $3 \mathrm{~min}$; then incubate for 39 cycles at: $94^{\circ} \mathrm{C}$ for $20 \mathrm{~s}, 58^{\circ} \mathrm{C}$ for $30 \mathrm{~s}, 72^{\circ} \mathrm{C}$ for $2 \mathrm{~min}$, with a final extension at $72^{\circ} \mathrm{C}$ for $10 \mathrm{~min}$.

4. Store PCR reaction at $4{ }^{\circ} \mathrm{C}($ see Note 3$)$.

5. Analyze the PCR products by standard agarose gel electrophoresis.

6. If a single PCR product of the expected size is detected, remove polymerase, dNTPs, and primers using a standard PCR cleanup kit.

7. If multiple products are detected, separate PCR products by gel electrophoresis, remove an agarose slice containing the required product and use a gel extraction kit to isolate the DNA from the agarose slice.

8. Elute the required PCR product from the cleanup or gel purification kit column in $\mathrm{dH}_{2} \mathrm{O}$.

9. Analyze the PCR product using an appropriate restriction enzyme or enzymes followed by standard agarose gel electrophoresis to confirm that the PCR product is as expected.

10. Quantify the nucleic acid concentration of the PCR product using NanoDrop 1000 or similar spectrophotometer.

11. Store the PCR product at $-20{ }^{\circ} \mathrm{C}$.

1. The gene fragment encoding the Fc part of human IgGl is PCR amplified from pFUSE-hIgGl-Fc2 with flanking restriction sites using the forward cgaattcagatctTGAGCC CAAATCTTGTGAC and reverse primer cggatccTCATT TACCCGGAGACAGG. Subsequently, the EcoRI/BamHI digested PCR fragment can be cloned into the EcoRI-BglII digested pCAGGS vector creating the pCAGGS-Fc vector.

2. Digest the SI PCR product and the pCAGGS-Fc vector by adding the following into separate $1.5 \mathrm{ml}$ tubes: $2 \mu \mathrm{l}$ of the appropriate $10 \times$ restriction buffer, $1 \mu \mathrm{g}$ of DNA (PCR product or vector), $\mathrm{H}_{2} \mathrm{O}$ up to $20 \mu \mathrm{l}, 20 \mathrm{U}$ of the appropriate 
restriction enzyme (EcoRI and $B a m \mathrm{HI}$ in the example in Subheading 2.1).

3. Mix gently by pipetting and incubate at $37^{\circ} \mathrm{C}$ for $1 \mathrm{~h}$.

4. Electrophorese the restriction digests of the vector and S1 PCR product in a agarose gel, identify the products and cut out the gel slices containing the digested products.

5. Purify the DNA products from the agarose slices using a gel extraction kit, elute the DNA into $\mathrm{H}_{2} \mathrm{O}$ and quantify the nucleic acid concentrations using a NanoDrop.

6. Ligate the digested SI PCR product into the pCAGGS-Fc vector by adding the following to a $1.5 \mathrm{ml}$ tube: $2 \mu \mathrm{l} \mathrm{10 \times \textrm {T } 4}$ ligation buffer, DNA of digested vector and SI PCR product in a 1:3 molar ratio, $\mathrm{H}_{2} \mathrm{O}$ up to $19 \mu \mathrm{l}, 1 \mu \mathrm{T} 4$ DNA ligase, mix gently by pipetting ( see Note 4 ).

7. Incubate the ligation mixture at $16^{\circ} \mathrm{C}$ for $1 \mathrm{~h}$.

8. Transform competent $E$. coli cells by adding $2-5 \mu \mathrm{l}$ of ligation mixture to $50 \mu \mathrm{l}$ competent cells.

9. Incubate on ice for $30 \mathrm{~min}$.

10. Heat-shock cells for $30 \mathrm{~s}$ at $42{ }^{\circ} \mathrm{C}$ in a thermocycler or water bath.

11. Add $250 \mu \mathrm{l}$ of SOC medium.

12. Incubate at $37^{\circ} \mathrm{C}$ for $1 \mathrm{~h}$ while shaking.

13. Plate $100 \mu \mathrm{l}$ on prewarmed LB Amp plates.

14. Incubate at $37^{\circ} \mathrm{C}$ overnight.

15. Next day, pick colonies using a sterile toothpick for colony PCR screening and storage.

\subsection{Colony PCR}

1. Transfer a small amount of a colony into $25 \mu \mathrm{l}$ of LB medium.

2. Make a PCR mix as follows: $2 \mu 110 \times$ PCR polymerase buffer, $1 \mu \mathrm{l} 10 \mathrm{mM}$ dNTPs, $0.6 \mu l 10 \mathrm{mM}$ forward primer, $0.6 \mu \mathrm{l}$ $10 \mathrm{mM}$ reverse primer, $1 \mu \mathrm{l}$ of the colony mix, $1 \mu \mathrm{PCR}$ polymerase, $13.8 \mu \mathrm{MlH}_{2} \mathrm{O}$.

3. Incubate the PCR mix for 30 cycles at $94^{\circ} \mathrm{C}$ for $20 \mathrm{~s}, 58^{\circ} \mathrm{C}$ for $30 \mathrm{~s}, 72^{\circ} \mathrm{C}$ for $2 \mathrm{~min}$, with a final extension at $72^{\circ} \mathrm{C}$ for $10 \mathrm{~min}$.

4. Analyze the PCR products by standard agarose gel electrophoresis.

5. Inoculate PCR positive clones in $2 \mathrm{ml} \mathrm{LB}$ Amp medium and to grow at $37^{\circ} \mathrm{C}$ for $\sim 8 \mathrm{~h}$ while shaking.

6. From this $2 \mathrm{ml}$ culture, inoculate $500 \mu \mathrm{l}$ into a $500 \mathrm{ml}$ of LB Amp medium.

7. Allow the bacteria to grow $\sim 8 \mathrm{~h}$ at $37^{\circ} \mathrm{C}$ while shaking.

8. Next day, extract plasmid DNA from the bacteria using a maxi prep DNA kit, according to manufacturer's instructions. 
9. Perform a restriction digest and analyze the products by standard agarose gel electrophoresis to confirm the plasmid DNA is correct.

10. Determine DNA concentration using a NanoDrop or spectrophotometer and prepare a DNA stock of $1 \mu \mathrm{g} / \mu \mathrm{l}$.

\subsection{Large-Scale Expression and Purification of S1-Fc Fusion Proteins}

1. Seed HEK-293T cells in 20 T175 flasks in $40 \mathrm{ml}$ of $293 \mathrm{~T}$ cell growth medium and incubate at $37{ }^{\circ} \mathrm{C}$ with $5 \% \mathrm{CO}_{2}$ for approximately 24 h until 60-70\% confluent.

2. Prepare a working stock of $1 \mathrm{mg} / \mu \mathrm{l}$ PEI. This can be kept at $4{ }^{\circ} \mathrm{C}$.

3. Two hours prior to transfection, remove medium from $293 \mathrm{~T}$ cells and replace with $30 \mathrm{ml}$ of fresh prewarmed 293T cell growth medium.

4. For each T175 flask, prepare the DNA transfection solution as follows: add $18 \mu \mathrm{l}$ of $1 \mu \mathrm{g} / \mu \mathrm{l}$ pCAGGS-MERS-CoV-S1-Fc plasmid DNA (Subheading 3.5, step 10) to $3 \mathrm{ml}$ of serumfree DMEM and mix by pipetting.

5. Add $54 \mu \mathrm{l}$ of $\mathrm{l} \mathrm{mg} / \mu \mathrm{l}$ PEI to the transfection solution and mix.

6. Incubate at room temperature for $30 \mathrm{~min}$.

7. Add the DNA/PEI complex dropwise to the T175 flask and gently swirl to mix.

8. Incubate cells 4-12 h (determine experimentally).

9. Aspirate the medium from the transfected cells and replace with $40 \mathrm{ml}$ of HEK-293T expression medium, incubate at $37{ }^{\circ} \mathrm{C}$ with $5 \% \mathrm{CO}_{2}$ for 6 days.

10. Prepare $50 \%(\mathrm{w} / \mathrm{v})$ protein-A sepharose beads: Add $0.25 \mathrm{~g}$ of protein-A sepharose CL-4B to a tube, add $10 \mathrm{ml}$ PBS to form a slurry, centrifuge for $2 \mathrm{~min}$ at $2,000 \times g$, remove supernatant, and repeat two more times. Pellet the beads for $2 \mathrm{~min}$ at $2,000 \times g$ and resuspend in $1.4 \mathrm{ml} \mathrm{PBS}$ per tube $(50 \% \mathrm{w} / \mathrm{v})$, the final volume will be $\sim 2.8 \mathrm{ml}$.

11. Collect the expression medium from the transfected HEK$293 \mathrm{~T}$ cells into $50 \mathrm{ml}$ tubes and centrifuge at $2,850 \times \mathrm{g}$ for $10 \mathrm{~min}$ to remove cell debris.

12. Transfer medium to new $50 \mathrm{ml}$ tubes and centrifuge again at $2,850 \times g$ for $15 \mathrm{~min}$.

13. Transfer cleared medium to new $50 \mathrm{ml}$ tubes and keep it on ice; take a $100 \mu \mathrm{l}$ aliquot and store at $-20{ }^{\circ} \mathrm{C}$.

14. Add $0.5 \mathrm{ml}$ of washed protein-A sepharose beads $(50 \% \mathrm{w} / \mathrm{v})$ and $800 \mu \mathrm{l}$ of $1 \mathrm{M}$ Tris- $\mathrm{HCl} \mathrm{pH} 8.0$ to each $40 \mathrm{ml}$ supernatant to neutralize the $\mathrm{pH}$ and incubate overnight, rotating at $4{ }^{\circ} \mathrm{C}$ ( see Note 5). 


\subsection{Immunopreci- pitation}

3.7.1 Preparation of Cell Lysate
3.7.2 Preclearing of the Huh-7cell Lysate
15. Collect the protein-A sepharose beads by centrifugation at $2,000 \times g$ for $15 \mathrm{~min}$ (see Note 6).

16. Pool all the protein-A sepharose beads together in a $50 \mathrm{ml}$ tube and wash three times with $10 \mathrm{ml}$ PBS.

17. After the final centrifugation, resuspend the protein-A sepharose beads in $1 \mathrm{ml}$ of $0.5 \mathrm{M}$ acetic acid $\mathrm{pH} 3$ elution buffer and incubate for $1 \mathrm{~min}$ at room temperature.

18. Centrifuge the protein-A sepharose beads at $14,000 \times g$ for $10 \mathrm{~min}$ and transfer the supernatant to a $1.5 \mathrm{ml}$ tube.

19. Repeat steps $\mathbf{1 7}$ and $\mathbf{1 8}$ twice more to elute any remaining Sl-Fc protein from the protein-A sepharose beads.

20. To remove any remaining protein-A sepharose beads in the supernatant repeat step $\mathbf{1 8}$ once and transfer supernatant to a fresh tube.

21. To neutralize the $\mathrm{pH}$ of the eluted S1-Fc protein, add $200 \mu \mathrm{l}$ of $3 \mathrm{M}$ Tris- $\mathrm{HCl} \mathrm{pH} 8.8$ (final $\mathrm{pH} 7.5$ ).

22. Quantify the protein concentration using a NanoDrop at $280 \mathrm{~nm}$.

23. To analyze the size of the eluted Sl-Fc protein, run $2 \mu \mathrm{g}$ of the protein in a standard $10 \%$ SDS-PAGE gel.

24. Aliquot the S1-Fc protein and store at $-80{ }^{\circ} \mathrm{C}$.

1. Seed $5 \times 10^{7}$ Huh-7 cells in $100 \mathrm{~mm}$ dishes with growth medium and incubate at $37^{\circ} \mathrm{C}$ for $24 \mathrm{~h}$ to allow the cells to become confluent.

2. Wash the adherent cells twice with ice-cold PBS and allow the PBS to drain off.

3. Add $1 \mathrm{ml}$ of DDM lysis buffer onto the cells and gently rock the dish to cover the entire cell sheet.

4. Scrape adherent cells off the dish with either a rubber policeman or a plastic cell scraper and transfer the cell suspension into a fresh centrifuge tube. Gently rock the suspension on either a rocker or an orbital shaker at $4{ }^{\circ} \mathrm{C}$ for $15 \mathrm{~min}$ to lyse the cells.

5 . Centrifuge the lysate at $14,000 \times g$ in a precooled microcentrifuge for $1 \mathrm{~min}$.

6. Immediately transfer the supernatant to a fresh centrifuge tube and discard the pellet.

1. Prepare a $50 \%(\mathrm{w} / \mathrm{v})$ protein-A sepharose bead slurry as in Subheading 3.6, step 10.

2. Add $100 \mu \mathrm{l}$ of the protein A-sepharose bead slurry to every $1.5 \mathrm{ml}$ of cell lysate and incubate at $4{ }^{\circ} \mathrm{C}$ for $10 \mathrm{~min}$ on a rocker or orbital shaker (see Note 7 ).

3. Remove the beads by centrifugation at $14,000 \times g$ at $4{ }^{\circ} \mathrm{C}$ for $1 \mathrm{~min}$ and carefully transfer supernatant to a fresh tube. 
3.7.3 Immunoprecipitation

\subsection{Mass \\ Spectrometry \\ Analysis by Nanoflow LC-MS/MS}

3.8.1 SDS-PAGE
1. Add $2.5 \mu \mathrm{g}$ of the purified Sl-Fc fusion protein (Subheading 3.6, step 24) to $1.5 \mathrm{ml}$ of the Huh-7 precleared lysate and incubate for $\mathrm{l} \mathrm{h}$ at room temperature on a rocker or an orbital shaker.

2. Use $1.5 \mathrm{ml}$ of the Huh-7 precleared lysate, without the purified S1-Fc fusion protein, as a negative control and incubate as described in step 1 .

3. Capture any immunocomplexes between the S1-Fc fusion protein and the precleared Huh-7 cell lysate by adding $150 \mu \mathrm{l}$ of the protein A-sepharose $50 \%$ bead slurry to $1.5 \mathrm{ml}$ of the lysates in Subheading 3.7, step 2, gently mix overnight at $4{ }^{\circ} \mathrm{C}$ on either a rocker or an orbital shaker.

4. Collect the protein A-sepharose beads by pulse centrifugation (i.e., $5 \mathrm{~s}$ in the microcentrifuge at $14,000 \times \mathrm{g}$ ). Discard the supernatant and wash the protein A-sepharose beads twice with DDM lysis buffer and once in PBS alone. Discard the supernatants.

5. Resuspend the protein A-sepharose beads in $200 \mu \mathrm{l}$ of PBS and store at $4{ }^{\circ} \mathrm{C}$.

1. Prepare $100 \mathrm{mM} \mathrm{NH}_{4} \mathrm{HCO}_{3}$-acetonitrile wash solution as follows: 1:1 (v:v) of $100 \mathrm{mM} \mathrm{NH}_{4} \mathrm{HCO}_{3}$ and acetonitrile.

2. Pellet $100 \mathrm{\mu l}$ of the protein A-sepharose beads (Subheading 3.7.3, step 5) by pulse centrifugation and discard the supernatant.

3 . Resuspend the protein A-sepharose beads in $30 \mu \mathrm{l} 2 \times$ TrisGlycine SDS sample buffer, mix gently and incubate at $100{ }^{\circ} \mathrm{C}$ for $10 \mathrm{~min}$ ( see Note 8 ).

4. Centrifuge at $14,000 \times g$ for $1 \mathrm{~min}$

5. Load $15 \mu \mathrm{l}$ of supernatant on a $10 \%$ pre-cast Tris-Glycine SDS-PAGE gel, electrophorese the sample for $40 \mathrm{~min}$ at $100 \mathrm{~V}$; Alternatively, the supernatant can be transferred to a fresh $1.5 \mathrm{ml}$ tube and stored frozen at $-20{ }^{\circ} \mathrm{C}$ for later use, frozen supernatants should be reboiled for $5 \mathrm{~min}$ directly prior to loading on a gel.

6. Transfer SDS-PAGE gel to a clean cell culture dish or other plastic container and cover with Coomassie blue staining solution. Incubate at room temperature for $45 \mathrm{~min}$ while shaking.

7. Destain the gel with destaining solution until bands can clearly be seen and leave the gel in $\mathrm{dH}_{2} \mathrm{O}$ in a clean cell culture dish.

8. Cut out the lane of interest using a clean razor blade and tweezers and put the complete lane onto two $\mathrm{dH}_{2} \mathrm{O}$-wetted filter papers $(1.5 \times 10 \mathrm{~cm})$.

9. Clean the razor blade of the Mickle gel slicer with methanol and then $\mathrm{dH}_{2} \mathrm{O}$. 
3.8.2 Destaining and Washing of Gel Pieces

3.8.3 Reduction and Alkylation of Proteins (See Note 10)
10. Place the filter paper with the gel lane on top onto the sled of the Mickle gel slicer and cut the gel lane into $1 \mathrm{~mm}$ slices.

11. Depending on the complexity of the protein mixture in the gel lane, transfer two or three adjacent slices to $1.5 \mathrm{ml}$ tubes that contain $600 \mu \mathrm{l}$ of $\mathrm{NH}_{4} \mathrm{HCO}_{3}$-acetonitrile wash solution, so that you divide the complete gel lane over 20-30 sample tubes.

1. Destain the gel slices by shaking at $4{ }^{\circ} \mathrm{C}$ overnight in the $100 \mathrm{mM} \mathrm{NH}_{4} \mathrm{HCO}_{3}$-acetonitrile wash solution (see Note 9).

2. Aspirate off the wash solution with a gel loading tip, replace with $0.5 \mathrm{ml}$ of fresh $\mathrm{NH}_{4} \mathrm{HCO}_{3}$-acetonitrile wash solution, and shake for $1 \mathrm{~h}$ at $4{ }^{\circ} \mathrm{C}$.

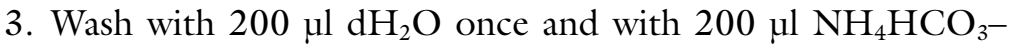
acetonitrile wash solution twice for $15 \mathrm{~min}$.

4. Shrink the gel pieces using $200 \mu 100 \%$ acetonitrile and flick the tube until the gel pieces turn white.

5. Incubate for $5 \mathrm{~min}$ at room temperature.

6. Aspirate off acetonitrile and air-dry the gel slices for $5 \mathrm{~min}$.

1. Freshly prepare gel swelling solution as follows: $5 \mathrm{ml} 100 \mathrm{mM}$ $\mathrm{NH}_{4} \mathrm{HCO}_{3}, 5 \mathrm{ml}$ freshly prepared $20 \mathrm{mM}$ DTT.

2. Freshly prepare alkylation solution as follows: Dissolve $102 \mathrm{mg}$ of Iodoacetamide (IAA) in $5 \mathrm{ml}$ of $\mathrm{dH}_{2} \mathrm{O}$ and then add $5 \mathrm{ml}$ of $100 \mathrm{mM} \mathrm{NH}_{4} \mathrm{HCO}_{3}$.

3. Swell each gel slice in $200 \mu \mathrm{l}$ gel swelling solution.

4. Incubate for $1 \mathrm{~h}$ at $37^{\circ} \mathrm{C}$.

5. Remove the gel swelling solution and add $200 \mu$ l alkylation solution to each gel slice.

6. Incubate for $\mathrm{l} \mathrm{h}$ at room temperature in the dark.

7. Wash the gel slices twice with $200 \mu \mathrm{l}$ of the $\mathrm{NH}_{4} \mathrm{HCO}_{3}$-acetonitrile wash solution for $15 \mathrm{~min}$.

8. Shrink the gel pieces in $200 \mu 100 \%$ acetonitrile.

1. Just before use, prepare a $10 \mu \mathrm{g} / \mathrm{ml}$ trypsin working solution by diluting the $100 \mu \mathrm{g} / \mathrm{ml}$ trypsin stock solution with $50 \mathrm{mM}$ $\mathrm{NH}_{4} \mathrm{HCO}_{3}$.

2. Add $10 \mu \mathrm{l}$ of the $10 \mu \mathrm{g} / \mathrm{ml}$ trypsin working solution to every $1 \mathrm{~mm}$ gel slice so that each slice is fully immersed in the trypsin working solution.

3. Incubate the gel slices for $30 \mathrm{~min}$ at room temperature.

4. Check that the gel pieces are still fully covered by the trypsin solution, if not, add some more trypsin working solution.

5. Incubate overnight at $37^{\circ} \mathrm{C}$; shaking not necessary. 
3.8.5 Extraction of Peptides from the Gel

3.8.6 Mass Spectrometry
1. Centrifuge the gel slices for $10 \mathrm{~s}$ and remove trypsin.

2. Add $50 \mu \mathrm{l}$ of the $0.5 \%$ formic acid solution in $30 \%$ acetonitrile peptide extraction solution, sonicate in an ultrasonic bath for $2 \mathrm{~min}$ at room temperature, then incubate for $30 \mathrm{~min}$ at room temperature.

3. Transfer the supernatant to a clean $1.5 \mathrm{ml}$ tube or into a 96-well plate.

4. Repeat steps $\mathbf{3}$ and $\mathbf{4}$ twice and combine the supernatants.

5. Dry the combined supernatants in a SpeedVac.

1. Dissolve the peptides in $30 \mu \mathrm{l}$ of $0.1 \%$ formic acid.

2. Analyze the samples by nanoflow LC-MS/MS on an EASYnLC coupled to a Q Exactive mass spectrometer, operating in positive mode and equipped with a nanospray source.

3. Trap peptide mixtures on a ReproSil C18 reversed-phase column (column dimensions $1.5 \mathrm{~cm} \times 100 \mu \mathrm{m}$, packed in-house) at a flow rate of $8 \mu \mathrm{l} / \mathrm{min}^{-1}$.

4. Separate peptides on a ReproSil C18 reversed-phase column (column dimensions $15 \mathrm{~cm} \times 50 \mu \mathrm{m}$, packed in-house) using a linear acetonitrile gradient from 0 to $80 \%(\mathrm{~A}=0.1 \%$ formic acid; $\mathrm{B}=80 \%(\mathrm{v} / \mathrm{v})$ acetonitrile, $0.1 \%$ formic acid $)$ in 70 or $120 \mathrm{~min}$ and at a constant flow rate of $200 \mathrm{nl} / \mathrm{min}^{-1}$.

5. Spray the column eluent directly into the electrospray ionization (ESI) source of the mass spectrometer.

6. Acquire mass spectra in continuum mode; fragment the peptides in data-dependent mode by higher-energy collisional dissociation (HCD).

7. For data analysis, create peak lists automatically from raw data files using a software suite such as Mascot Distiller software (Matrix Science), Proteome Discoverer (Thermo), or MaxQuant. Use a database search engine such as Mascot or Andromeda (MaxQuant) for searching peak lists against a Uniprot fasta database that contains all human protein sequences. For control purposes, merge the human protein database with a fasta database containing all for example MERS virus protein sequences. Perform the database search analysis on either an in-house server or a multi-core desktop PC.

8. Human Dipeptidyl peptidase 4 (DPP4 or CD26) tryptic peptides are expected to be detected specifically in MERS-CoVSl-Fc IP samples, in relation to the examples given. 


\subsection{Cloning and Expression of Human DPP4 or Appropriate Receptor}

3.9.1 RNA Isolation and PCR Amplification of Human DPP4

\subsubsection{Cloning and Expression of Human DPP4}

\subsubsection{Identification} Receptor Expressing Cells by Flow Cytometry Analysis
1. Isolate total RNA from Huh-7 cells and make cDNA as described in Subheadings 3.1 and 3.2.

2. Amplify complete human DPP4 using Pfu Ultra II fusion HS DNA polymerase using the PCR protocol described in Subheading 3.3 using specific primers for human DPP4 or the gene sequence of the protein of interest.

1. Clone the complete DPP4 gene or gene of interest into the pcDNA $3.1(+)$ expression vector into the BamHl and NotI site (pcDNA-hDPP4 plasmid).

2. Check the construct by sequence analysis.

Prepare cells not susceptible to virus infection (e.g., Cos-7 cells) and transfect them with the DPP4-expression plasmid. Transfect pcDNA-hDPP4 using PEI (plasmid PEI ratio 1:3)

3. At $24 \mathrm{~h}$ post transfection the cells can be tested for the cell surface expression of DPP4 using FACS analysis and susceptibility of infection by infecting those cells with MERS-CoV-EMC.

1. After $24 \mathrm{~h}$ of transfection (Subheading 3.9.2, step 2), wash the cells once with PBS and add $1 \mathrm{ml}$ of Trypsin EDTA.

2. Incubate at $37^{\circ} \mathrm{C}$ for approximately $5 \mathrm{~min}$ (until complete disassociation of the cells).

3. Add $1 \mathrm{ml}$ of PBS and mix it by pipetting up and down.

4. Transfer the cell suspension in to a new tube and add additional $5 \mathrm{ml}$ of PBS.

5. Centrifuge at $400 \times g$ for $5 \mathrm{~min}$.

6. Resuspend the cells in $2 \mathrm{ml}$ PBS and count the cells using the counting chamber.

7. Place $5 \times 10^{5}$ cells in a 96 well " $\mathrm{v}$ " bottom plate and add S1-Fc or $5 \mu \mathrm{g} / \mathrm{ml}$ antibody against protein under investigation such as goat anti-DPP4 polyclonal antibodies in this example, or without any protein as a control, in volume of $50 \mu \mathrm{l}$.

8. Incubate on ice for $30 \mathrm{~min}$.

9. Wash the cells three times with PBS containing $0.5 \% \mathrm{BSA}$.

10. Add $50 \mu \mathrm{l}$ of FITC-labelled goat anti-human IgG or FITClabelled rabbit anti goat serum $(5 \mu \mathrm{g} / \mathrm{ml})$ or any other labelled secondary antibody depending on the origin of the antibody in step 7 .

11. Incubate on ice for $30 \mathrm{~min}$ and wash the cells three times with PBS.

12. Resuspend the cells in $190 \mu$ of PBS.

13. Analyze the cells for any fluorescence by flow cytometry (Fig. 2). 

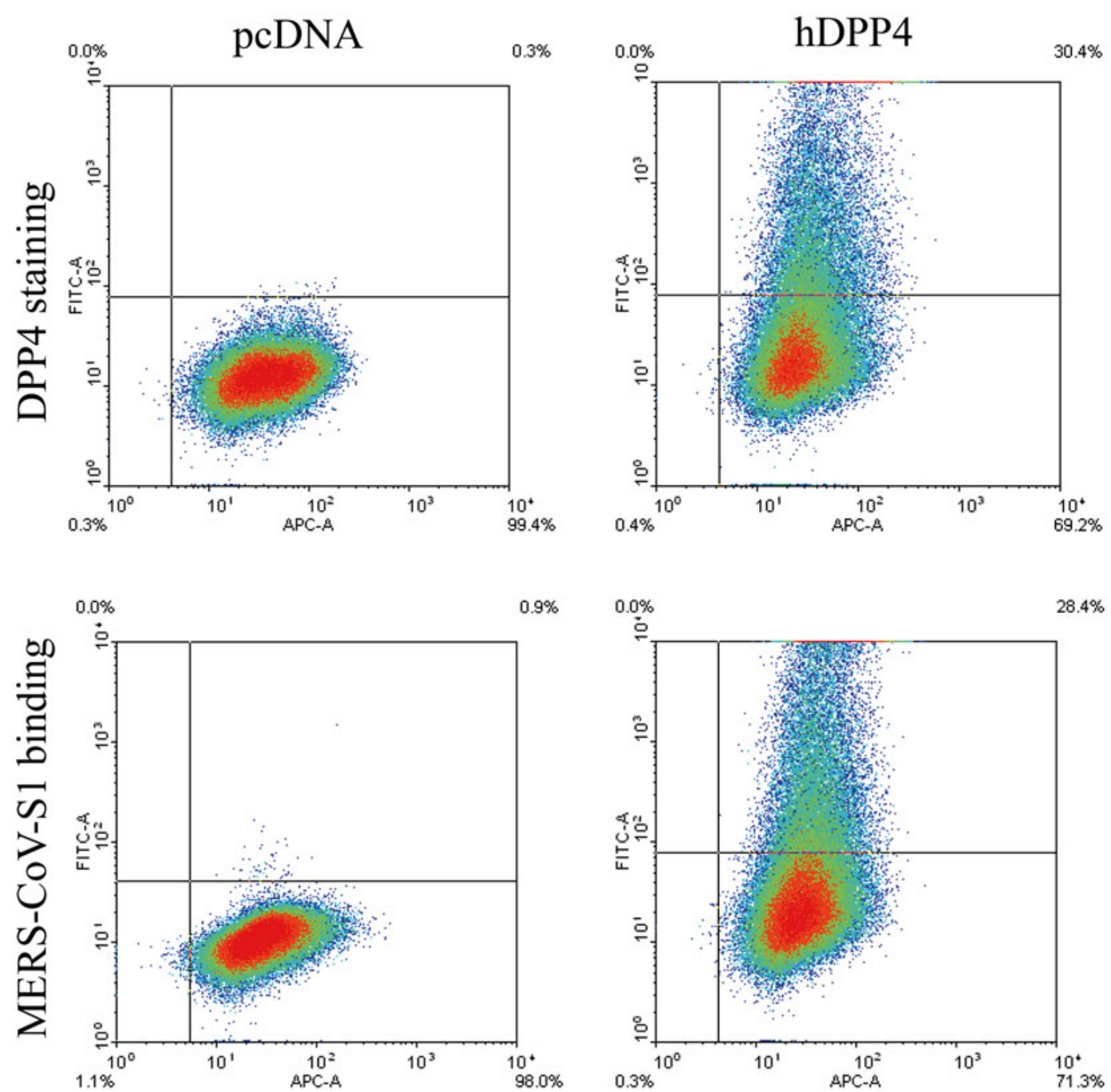

Fig. 2 Human DPP4 expression and MERS-CoV-S1 binding to cells transfected with human DPP4 plasmid or empty plasmid as analyzed by FACS analysis. DPP4 staining (upper panel) and MERS-CoV-S1 binding (lower panel) are shown

3.9.4 Virus

Infection Assay
1. Transfect pcDNA-DPP4 plasmid or plasmid containing the gene under investigation in Cos-7 and empty plasmid as control.

2. After $24 \mathrm{~h}$ of transfection, wash the cells with Cos-7 growth medium and incubate the cells with virus under investigation, e.g., MERS-CoV-EMC for $1 \mathrm{~h}$.

3 . Wash the cells two times with Cos-7 growth medium containing $1 \%$ FCS to remove any unbound virus and after final wash add $3 \mathrm{ml}$ of fresh medium.

4. Incubate the cells at $37^{\circ} \mathrm{C}$ with $5 \% \mathrm{CO}_{2}$ for $24 \mathrm{~h}$.

5. Fix the cells with $4 \%$ formaldehyde solution for $10 \mathrm{~min}$. 
6. Wash the cells three times with PBS.

7. Add $500 \mu \mathrm{l}$ of $70 \%$ ethanol and keep the plate at $4{ }^{\circ} \mathrm{C}$ until immunofluorescent staining.

8. Wash the cells three times with PBS.

9. Add $200 \mu \mathrm{l}$ of $10 \%$ normal goat serum or serum corresponding to the species from which the secondary antibody in step 14 is derived.

10. Incubate the cells at $37^{\circ} \mathrm{C}$ for $30 \mathrm{~min}$.

11. Remove the $10 \%$ normal goat serum and add $200 \mu$ of any antibody to a specific virus protein, for example rabbit-antiSARS-CoV nsp4 $(5 \mu \mathrm{g} / \mathrm{ml})$ is cross-reactive for MERS-CoV-EMC.

12. Incubate the cells at $37^{\circ} \mathrm{C}$ for $1 \mathrm{~h}$.

13. Wash the cells three times with PBS.

14. Add $200 \mu \mathrm{l}$ of goat anti-rabbit serum conjugated with FITC $(5 \mu \mathrm{g} / \mathrm{ml})$.

15. Incubate the cells at $37^{\circ} \mathrm{C}$ for $\mathrm{l} \mathrm{h}$.

16. Wash the cells three times with PBS and analyze using a fluorescent microscope (Fig. 3).

a

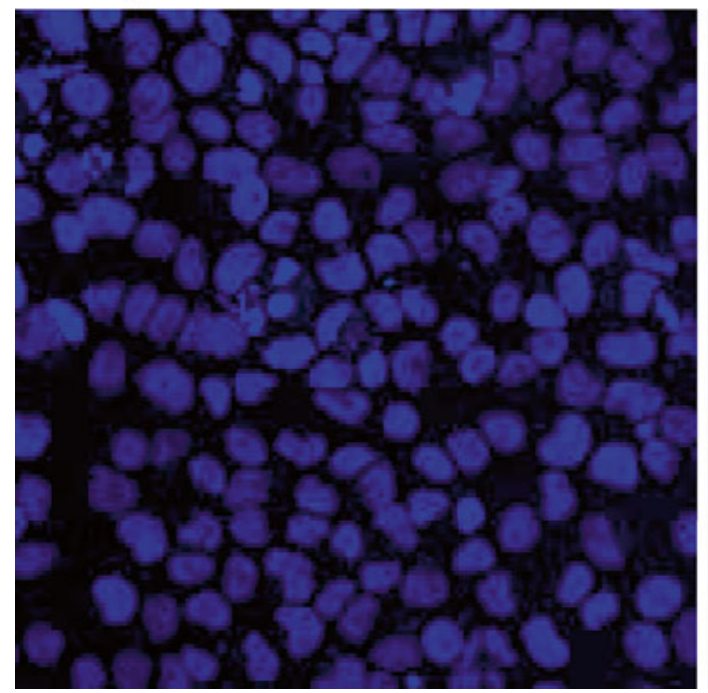

b $\quad \mathrm{hDPP} 4+\mathrm{MERS}-\mathrm{CoV}$

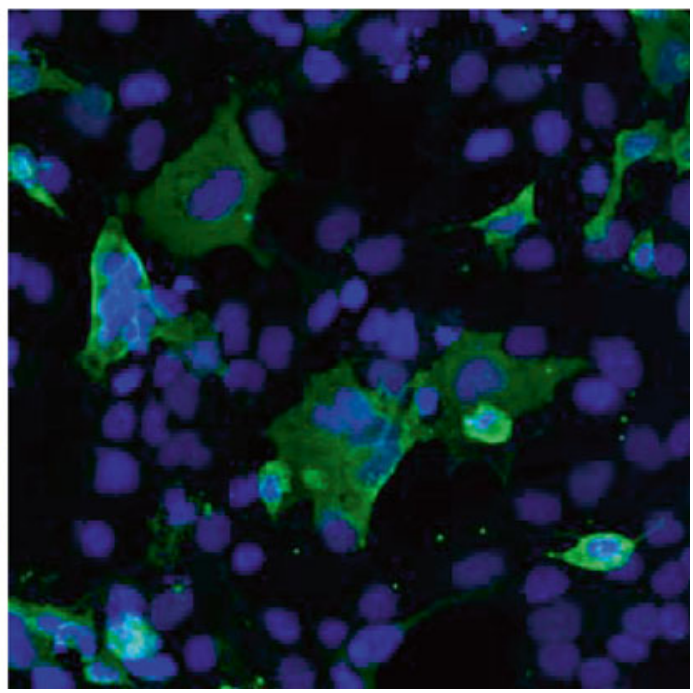

Fig. 3 Characterization of human DPP4 as a functional receptor for MERS-CoV. Human DPP4 plasmid or a control plasmid was transfected in non-susceptible Cos-7 cells and after $24 \mathrm{~h}$ the cells were infected with MERS-CoV-EMC. Subsequently, the cells were fixed after $24 \mathrm{~h}$ of infection and stained for MERS-CoV. (a) Empty plasmid transfected cells. (b) Human DPP4 plasmid transfected cells 


\section{Notes}

1. When using another RNA isolation kit, please refer to the recommendations of the respective manufacturer.

2. The amount of RNA that can be used for this reaction volume is $100 \mathrm{pg}$ to $1 \mu \mathrm{g}$ RNA. If more RNA is used, (e.g., $2 \mu \mathrm{g}$ ), add the appropriate amount of reagents needed.

3. When using another polymerase than Pfu, please refer to the recommendations of the respective manufacturer.

4. Add the ligase last.

5. It is recommended to cut the tip of the pipette-tip off when working with sepharose beads to avoid disruption of the beads.

6. Before aspiration of the medium, take a $100 \mu \mathrm{l}$ aliquot and store at $-20{ }^{\circ} \mathrm{C}$.

7. Preclearing the lysate will reduce nonspecific binding of proteins to the agarose or sepharose when it is used later on in the assay.

8. Be sure that all equipment that you use for running gels (trays, boxes, dishes, tips, etc.) is clean and try to keep equipment that you use for mass spec gels apart from other electrophoresis equipment in your lab. The more the keratin contaminants, the less the protein identifications in the end.

9. A few hours is sufficient.

10. These steps can be skipped if you have alkylated the proteins before running the gel.

\section{Acknowledgement}

This work was supported by a grant from the Dutch Scientific Research (NWO; no. 40-00812-98-13066) granted to BJB and BLH. SLS is partly employed by Viroclinics Biosciences.

\section{References}

1. Parrish CR, Holmes EC, Morens DM et al (2008) Cross-species virus transmission and the emergence of new epidemic diseases. Microbiol Mol Biol Rev 72:457-470

2. Drosten C, Günther S, Preiser W et al (2003) Identification of a novel coronavirus in patients with severe acute respiratory syndrome. N Engl J Med 348:1967-1976
3. Zaki AM, van Boheemen S, Bestebroer TM et al (2012) Isolation of a novel coronavirus from a man with pneumonia in Saudi Arabia. N Engl J Med 367:1814-1820

4. Dalgleish AG, Beverly PCL, Clapham PR et al (1984) The CD4 (T4) antigen is an essential component of the receptor for the AIDS retrovirus. Nature 312:763-767 
5. Greve JM, Davis G, Meyer AM, Forte CP et al (1989) The major human rhinovirus receptor is ICAM-1. Cell 56:839-847

6. Bergelson JM, Shepley MP, Chan BMC et al (1992) Identification of the integrin VLA-2 as a receptor for echovirus 1 . Science 255:1718-1720

7. Mendelsohn CL, Wimmer E, Racaniello VR (1989) Cellular receptor for poliovirus: molecular cloning, nucleotide sequence, and expression of a new member of the immunoglobulin superfamily. Cell 56:855-865

8. Yeager CL, Ashmun RA, Williams RKet al (1992) Human aminopeptidase $\mathrm{N}$ is a receptor for human coronavirus 229E. Nature 357:420-422

9. Raj VS, Mou H, Smits SL et al (2013) Dipeptidyl peptidase 4 is a functional receptor for the emerging human coronavirus-EMC. Nature 495:251-254

10. Li W, Moore MJ, Vasilieva $\mathrm{N}$ et al (2003) Angiotensin-converting enzyme 2 is a functional receptor for the SARS coronavirus. Nature 426:450-454

11. Zeng Q, Langereis MA, van Vliet AL et al (2008) Structure of coronavirus hemagglutinin-esterase offers insight into corona and influenza virus evolution. Proc Natl Acad Sci U S A 105:9065-9069

12. van Boheemen $S$, de Graaf M, Lauber C et al (2012) Genomic characterization of a newly discovered coronavirus associated with acute respiratory distress syndrome in humans. MBio 3, e00473-12 